\title{
Correction to: Hybrid sterility increases with genetic distance in snubnose darters (Percidae: Etheostoma)
}

\author{
Michael D. Martin • Tamra C. Mendelson
}

Published online: 18 December 2017

(C) Springer Science+Business Media B.V., part of Springer Nature 2017

\section{Correction to: Environ Biol Fish}

https://doi.org/10.1007/s10641-017-

0672-4

The original version of this article unfortunately contained a mistake. The correct equation is now given below.

$\mathrm{HS}=\frac{f_{c}-f_{h}}{f_{c}+f_{h}}$

Also in page 2, "where $f_{y} \ldots$ " is rewritten as "where $f_{h} \ldots$...

The original article was corrected.

The online version of the original article can be found at https://doi.org/10.1007/s10641-017-0672-4

M. D. Martin - T. C. Mendelson

Department of Biological Sciences, University of Maryland,

Baltimore County, Baltimore, MD 21250, USA

Present Address:

M. D. Martin $(\bowtie)$

Department of Biology, Oxford College of Emory University,

110 Few Circle, Oxford, GA 30054, USA

e-mail: michael.martin@emory.edu 